\title{
Understanding the persistence of history-related issues in Sino-Japanese relations: from memory to forgetting
}

\author{
Karl Gustafsson ${ }^{1,2}$ (D) \\ Published online: 30 January 2020 \\ (C) The Author(s) 2020
}

\begin{abstract}
Disputes over collective memory are a common source of bilateral friction in international politics. For example, differences over war memory have negatively impacted Sino-Japanese relations for many decades, despite apologies and other attempts to deal with the problems. Why are history-related issues so persistent? Existing explanations suggest, for example, that efforts to improve relations have been insufficient, or that collective memory is used instrumentally for political expediency. This article contributes to this discussion by shifting the conceptual focus from memory to forgetting. It argues that dominant notions of forgetting as fading away and denial often facilitate an understanding of collective memory in terms of security. It suggests that a conceptualization of forgetting that sees it as inherent to all remembering could ameliorate tension over collective memory by making those involved in international memory politics recognize that not only others forget, but that they themselves also do so as they remember.
\end{abstract}

Keywords Collective memory $\cdot$ Forgetting $\cdot$ Security $\cdot$ Foreign policy $\cdot$ China $\cdot$ Japan

\section{Introduction}

Bilateral disagreements over how to remember the past are common in international politics. Such disputes often play a central role in intractable conflicts over territory and resources, making them even more difficult to resolve. In some cases, collective memory-related disputes continue to disturb interstate relations even though attempts are made to improve relations and overcome differences over how the past is remembered.

Karl Gustafsson

karl.gustafsson@ekohist.su.se

1 Department of Economic History and International Relations, Stockholm University, Universitetsvägen 10, 10691 Stockholm, Sweden

2 Swedish Institute of International Affairs, PO Box 27035, 10251 Stockholm, Sweden 
Relations between China and Japan present us with a case that epitomizes the persistence of history-related issues. Collective memory related to Japanese aggression in China in the 1930s and 1940s has negatively impacted bilateral relations for many decades. After the war, Japan adopted a constitution which is often referred to as 'pacifist', and has subsequently stuck to a peaceful path. Sino-Japanese relations then developed from a situation in which Japan did not even recognize the People's Republic of China (PRC) to normalization of bilateral relations in 1972. In addition, Japanese prime ministers and other government representatives have made numerous apologies. Nonetheless, history-related problems have not gone away. Why have conflicts over collective memory persisted in relations between Japan and China despite efforts to deal with the issue, for example through high-level apologies? The Sino-Japanese case can shed light on general questions related to international memory politics: Why are disputes over collective memory so persistent? Why are the foreign policy actions that are meant to ameliorate collective memory often insufficient and unsuccessful?

In research on Sino-Japanese relations, several existing explanations can be found: Some have suggested that apologies have been insufficient or inefficient because they have been followed by actions by Japanese politicians that are seen as nullifying them, such as the denial of the aggressive nature of Japan's invasion of China. Others have argued that the problem persists because collective memory is used for political expediency, for example by the Chinese government or right-wing Japanese politicians. According to another argument, the problem persists because collective memory is key to fulfilling identity needs. While these explanations all highlight important aspects of Sino-Japanese memory politics, this article seeks to contribute by shifting the focus from memory to forgetting. The growing literature on how the politics of the past influence foreign policy and international relations has used concepts such as collective memory, trauma and remembrance, while the concept of forgetting has not been discussed in much detail. This article draws on recent work in memory studies where a conceptual shift from memory to forgetting has started to occur (e.g. Augé 2004; Connerton 2008; Whitehead 2009: 154; Plate 2016). It argues that shifting the focus from memory to forgetting and engaging in depth with the concept of forgetting can advance our understanding of international memory politics in general and why such issues are so persistent in particular. In doing so, the article discusses different understandings of forgetting and how they impact on international memory politics.

Crucially for understanding why history-related problems have been so persistent, the notions of forgetting that dominate in Sino-Japanese memory politics-as fading away and as denial - tend to discuss forgetting in terms of security. Importantly, forgetting as fading away involves seeing memory as threatened by forgetting even in the absence of any securitizing move or threatening actor. Forgetting as fading away is passive, and it is believed that it will occur unless we guard against it. Various actors seek to protect the collective memories that they espouse from the threat of fading away through a range of measures, for example by constructing museums, memorials, archives and by holding commemorative ceremonies. Forgetting as denial, by contrast, is active. It involves other actors denying 'our' memory. In the 
face of denial, they often escalate their activities and seek international recognition of the memories they hold dear.

While these two influential ways of understanding forgetting are useful for understanding much of what goes on in Sino-Japanese memory politics, they are nonetheless incomplete. They fail to take into account that forgetting is also productive. A third notion of forgetting that regards it not simply as a 'failure of memory-a disremembering' (Plate 2016: 144), but as a 'component of memory itself' (Augé 2004: 15), it is argued, can help us better understand international memory politics. The various measures that are used to prevent forgetting at the same time actively produce it. Active forgetting thus appears not only in the form of denial but is also inherent to remembering itself (Plate 2016: 144). If international memory politics were to be informed by such a conceptualization of forgetting and those involved in it were to recognize that not only others forget, but that we all do so as we remember, it could ameliorate bilateral tension over collective memory.

The next section briefly reviews research on international memory politics in International Relations (IR) in general, and in the context of Sino-Japanese relations in particular, highlighting some of the preoccupations and limitations of this literature. Following this review, the article moves on to a discussion of the concept of forgetting. The section that then follows explores and provides examples of how this discussion of forgetting can inform our understanding of Sino-Japanese memory politics. The conclusion further discusses the implications of the findings of the analysis and provides suggestions for future research.

\section{Collective memory in international relations}

The political and social significance of how societies remember the past has received increased scholarly attention in the past decades. This growing IR literature has suggested that conflicts over collective memory are difficult to resolve. Why is this? Why are disputes over collective memory so persistent?

In research on the empirical case with which this article is concerned, that is Sino-Japanese relations, several existing explanations can be identified: Some have suggested that Japanese attempts to resolve the issue, for example through expressions of remorse, have been insufficient or that they have failed because they have been followed by actions by Japanese politicians that are seen as nullifying them, such as the denial of the aggressive nature of Japan's war (e.g. Lind 2008; Suzuki 2008; Gustafsson 2019a). There is some truth to such explanations. At the same time, however, they sometimes appear to focus excessively on the apologies per se or on how they are received within Japan, while paying insufficient attention to the role of Chinese collective memory.

Others have argued that collective memory is used for political expediency, for example by the Chinese government or right-wing Japanese politicians (e.g. He 2009; Wang 2012; Pugliese and Insisa 2017). It is thus believed that the Chinese government has used references to Japanese wartime aggression to seek to extract concessions from Japan. However, even though such attempts certainly have been made and may have been relatively successful in the past, more recently they have 
been less successful as many Japanese have come to believe that Japan has apologized sufficiently (e.g. Fukuoka 2018). Others argue that state actors use war memory to increase legitimacy or to put pressure on the other state. While politicians certainly do attempt to use collective memory strategically, such arguments suggest that government actors are more or less in control of collective memory and able to switch the issue on and off as they please. However, even when both sides have tried to improve relations, as they did for example around 2007-2008 when several highlevel state visits took place, the results were relatively modest.

According to another argument, the issue persists not because it is used strategically but because collective memory is central to the fulfilment of identity needs: attachment to identity is understood as so important that it trumps attempts at improving relations. As a result, nationalist, rather than conciliatory or cosmopolitan commemoration, has dominated. This presents an obstacle to resolving disputes over collective memory (e.g. Rose 2005; Zarakol 2010; Gustafsson 2014; Shibata 2016; Saito 2016). This article is sympathetic to and overlaps in part with this approach, but seeks to contribute to it by highlighting the key role played by forgetting in constructing and maintaining a coherent sense of self.

The perspectives discussed above all present important findings that arguably have some bearing on the persistence of disputes over collective memory. The point of this article is thus not to dismiss, but to complement existing scholarship. In doing so, it seeks to contribute not only to research on Sino-Japanese relations, but to research on the international politics of memory more broadly. This broader literature has explored the links between collective memory and foreign policy (Müller 2002; Zehfuss 2007; Laffey and Weldes 2008; Lawson and Tannaka 2010; Subotić 2019b; Pusca 2014; Dian 2017; Klymenko 2019), the role of trauma in international politics (Edkins 2003; Bell 2006; Resende and Budryte 2013; Klymenko 2016), how the legacies of past wars influence interstate reconciliation (Rose 2005; Auerbach 2009; Mannergren Selimovic 2017; Siddi 2017; Khoury 2018; Gustafsson 2019b), the securitization of collective memory (Mälksoo 2014; Strukov and Apryshchenko 2018) and the relationship between memory and ontological security (Zarakol 2010; Gustafsson 2014; Mälksoo 2015; Rumelili 2018; Subotić 2019a). Even though some of this IR scholarship does refer to forgetting, and the existence of a dialectic between remembering and forgetting is sometimes acknowledged, most research focuses on memory and does not discuss forgetting in detail. In shifting the focus from memory to forgetting, the next section raises and addresses fundamental questions concerning the relationship between forgetting and security, such as what exactly constitutes existential threats and security measures in the context of international memory politics (cf. Buzan et al. 1998: 22-23).

\section{From memory to three kinds of forgetting}

In memory studies, a 'discursive shift' has already started to 'take place from memory to forgetting' (Whitehead 2009: 154). Some have argued for a move from memory studies to oblivion studies (Plate 2016). As part of this ongoing turn, scholars have begun to explore the concept of forgetting not just as the loss of or the flipside 
of memory, but as a concept in its own right which is considerably more complex than often suggested. It has thus been argued that forgetting is not a singular concept. Instead, there are different types of forgetting that occur in different ways. Paul Connerton, for example, has argued (2008), based on numerous historical examples, that there are at least seven types of forgetting. Others have responded that some of the kinds of forgetting that Connerton identifies can be subsumed within a smaller number of categories (Erdelyi 2008; Singer and Conway 2008; Wessel and Moulds 2008a). In what follows below, I will first discuss three understandings of forgetting that I suggest are particularly useful for understanding Sino-Japanese memory politics.

\section{Memory as fading away and denial}

For Maurice Halbwachs, who coined the term 'collective memory', to view memory as collective means that people are seen as remembering the past as members of groups. These groups construct memory collectively through a selective process where the group's past is reconstructed in the light of the present (Halbwachs, 40). In Halbwachs view, collective memory is primarily shared through everyday communication among those who experienced events. As they gradually pass away, the memory of what happened in the past often fades away (Halbwachs 1992). For Halbwachs then, forgetting is understood as a passive fading away of memory. Many scholars who have built on Halbwachs' work have similarly been concerned with memory rather than forgetting and as such have also tended to approach forgetting primarily in terms of such a passive fading away of memory.

The common understanding of forgetting as passive can be traced to its etymological roots. 'Forgetting' in languages such as English and German means loss of memory or failure to remember (Plate 2016: 145). The Japanese (忘れる, wasureru) and Chinese (忘, wáng) terms have similar meanings. The Chinese character wáng (忘) consists of two parts, one of which means to die or lose (亡), while the other means heart, feeling or mind (心). In other words, to forget in Japanese and Chinese means to lose that which previously was in one's heart (or mind) (Tōdō et al. 2018). Given these etymological roots, it is understandable that forgetting often tends to be understood as a passive fading away. Much of the academic literature echoes this understanding (Plate 2016: 145). However, the Latin word 'oblivion' has a different etymology: 'Oblivion refers to the condition or state of being forgotten. Its Latin root, "oblivisci", means "to take away", and so suggests it is active, not the passive loss of memory implied by its Germanic counterpart' (Plate 2016: 146).

The other common understanding of forgetting is active and actor-centric. It sees the threat of forgetting in terms of denial (cf. Wessel and Moulds 2008b; Connerton 2008: 60-61). It identifies actors who are seen as seeking to deny collective memory. In international memory politics, it is typically other states or actors associated with those states that are depicted as seeking to deny memory. The observation that collective memory is 'seen to be at risk ... by dying generations and official denial' (Olick et al. 2011: 4) illustrates that fading away and denial are two conceptualizations of forgetting that are regarded as operating at the same time. 
Importantly, forgetting, both as fading away and as denial, tends to be seen as almost inherently bad and threatening. In memory studies, commentary about a contemporary pervasiveness of a fear of forgetting as well as a view of forgetting as a threat is abundant. Forgetting is often understood as negative, while remembering is seen as positive. Some even describe forgetting as a 'villain' and remembering as a 'hero'. Others speak of forgetting as 'terror' and a 'cardinal sin' (Plate 2016: 145). For example, it has been stated that: 'our secular culture today, obsessed with memory as it is, is also somehow in the grips of a fear, even a terror, of forgetting' (Huyssen 2000: 28). The fact that even within memory studies, forgetting is often spoken of as a 'villain', 'terror' and 'sin' against which precautions must be taken, shows the extent to which discussions of forgetting tend to be permeated by a language of security.

In terms of securitization theory (Buzan et al. 1998), for many actors involved in memory politics, as well as for many scholars of collective memory, it appears that forgetting as fading away and denial are understood as existential threats to collective memory. In securitization theory, actors turn issues into security problems through securitizing moves. By contrast, when it comes to forgetting as fading away, it seems that collective memory is understood as a security issue even in the absence of a securitizing move and in the absence of a threatening enemy. This means that security measures are adopted even when a particular collective memory is not threatened by an enemy. It thus seems that compared to many other issues collective memory might be particularly susceptible to securitization. It is almost as if to some degree it is always securitized. The language we use to speak of memory and forgetting seems to be complicit in the securitization of collective memory. This means that when a statement or act is interpreted as denial this happens in a context where memory is already thought of in terms of security. The actor-centric forgetting as denial involves seeing a particular agent as responsible for the threat.

There are numerous measures for preventing forgetting. At the individual level, we might tie a piece of string around a finger, set an alarm or write down what we wish not to forget on a blackboard. At the societal level, collectives use cultural resources - they construct monuments, museums, libraries and archives, and organize commemorative ceremonies to prevent memory from fading away. Jan Assmann has thus suggested that '[i]f we concede that forgetting is the normality of personal and cultural life, then remembering is the exception, which-especially in the cultural sphere-requires special and costly precautions. These precautions take the shape of cultural institutions' (2011: 335). Others speak of 'technologies of memory' that make it possible to record memories in different ways and thereby increase our capacity to remember and reduce the risk of forgetting (1999: 342), or an 'infrastructure dedicated to keep the memory alive-consisting of memorials, museums, documentation, curricula, commemorations and civil societal organizations' (Langenbacher 2010: 29). Such initiatives and sites of memory are seen as necessary to 'block the work of forgetting' and thereby help collectives remember the past (Nora 1996: 19). Forgetting as denial, by contrast, often triggers international efforts to gain support and recognition for the memory that is seen as being denied as well as harsh criticism of the actor seen as responsible for denial. 


\section{Forgetting as inherent to remembering}

Importantly, the influential understandings of forgetting as passive fading away and active denial are incomplete. Forgetting, both individual and collective, also occurs in more subtle and not necessarily conscious ways, for example through retelling and adaptation (Stone and Hirst 2014). Forgetting, in such an understanding, is 'not so much the dissipation of the original trace but a result of the cumulative reconstructions of successive rememberings which, over months and years', result in 'a progressively less faithful rendition of the original story' (Erdelyi 2008: 274). Others view the interplay between remembering and forgetting in terms of 'doing gardener's work, selecting, pruning. Memories are like plants: there are those that need to be quickly eliminated to help the others burgeon, transform, flower' (Augé 2004: 17). Forgetting, in other words, is necessary in order to cope, if not to survive (e.g. Erdelyi 2008: 275). We forget through reinterpretation and retelling and thereby turn uncomfortable memories into ones we can more easily live with. We adapt our memories and forget some experiences in order to be able to function and go on. We cannot remember everything. All the information would overwhelm and confuse us. Our memory would become 'saturated' (Augé 2004: 20), and it would make it impossible for us to maintain a coherent sense of self. We therefore exclude and forget what does not fit (Wessel and Moulds 2008a: 290). On an individual level, this is done through autobiographical memory, that is 'recollections of personally experienced events' (Wessel and Moulds 2008b: 291). The insight that we remember in ways that enable us to have a coherent sense of self is similar to arguments that stress the importance of a biographical narrative for ontological security (Steele 2008), but further specifies the role of forgetting in the construction of such autobiographies.

Autobiographical memory is reconstructive in that when we remember it is not just as if we retrieve records from an archive. Instead, we 'reassemble information about earlier experiences according to present goals, beliefs and concerns' (Wessel and Moulds 2008b: 291). Such autobiographical memory is key to constructing and maintaining, as well as to adjusting, a coherent and continuous sense of self, which helps guide present and future behaviour. Forgetting helps groups construct a coherent sense of self in at least two ways-(1) through active and deliberate attempts to make the past fit with the group's current goals, and (2) as a consequence of the passive and often unconscious ways in which what is in line with the group's selfunderstanding and goals is incorporated while that which does not fit is excluded (Wessel and Moulds 2008a: 290-291). In for example museum exhibitions, we see how current goals are emphasized in the lessons the exhibitions convey to visitors. Museums and archives provide limited storage places that make up the group's collective knowledge base. In the same way, officially sanctioned commemorative activities also require funding and a selection therefore needs to be made (Wessel and Moulds 2008a: 290-291, 2008b: 294-295). This selection tends to be made in a way that seeks to maintain a coherent sense of self and highlights current and future goals or lessons.

Viewed from this perspective, Pierre Nora's large inventory of French 'sites of memory' (lieux de memoire) can be criticized for omitting uncomfortable and divisive episodes in France's past and for not sufficiently paying attention to 'sites of 
forgetting' (lieux d'oubli). Most notably in this regard, Nora has been criticized for omitting much of the history of French imperialism (Anderson 2004).

In the context of international politics, autobiographical memory can be useful for connecting with others and establishing relationships. By talking with others about our pasts, we reveal who we are. Based on such revelations, we can connect with those who share similar past experiences, thereby strengthening our relationships (Wessel and Moulds 2008b: 291-292). By changing how it remembers past occurrences, a state might redefine its relations with other states that it went to war with in the past, thereby making possible more conciliatory relations. They may also seek to deepen relations or even form alliances with other states by stressing shared or similar experiences. UNESCO's World Heritage and Memory of the World programs provide platforms for safeguarding memory and heritage meant to be shared by humanity as a whole. These initiatives are based on conceptions of forgetting as fading away (e.g. UNESCO 1972; Zon 1999). For individual states, these programs offer opportunities for safeguarding their collective memory from forgetting as fading away and denial by gaining international recognition. However, such initiatives may also exacerbate conflict over memory since they further expose different collectives not only to each other's autobiographical memory but also to their forgetting. In other words, the internationalization of memory arguably makes contestation more likely since what one group has forgotten in the process of remembering may very well be what another remembers. In such cases, we may see states compete for international recognition. The next section explores how such competition plays out in Sino-Japanese relations.

\section{Forgetting and Sino-Japanese relations}

This section illustrates how forgetting as outlined in the previous section can help shed light on Sino-Japanese bilateral memory politics by focusing on the memory of the 1937 Nanjing massacre and the atomic bombing of Hiroshima. These brief empirical illustrations are not meant to exhaust but only to exemplify some ways in which the discussion of forgetting above can inform analysis of international memory politics.

\section{Forgetting as fading away}

Understanding forgetting as fading away entails viewing it as a threat that exists even in the absence of an enemy seen as attacking a memory by denying it. The construction of museums, memorials and archives constitutes key measures for protecting collective memory from fading away. 
In both China and Japan, hundreds of museums deal in different ways with the war that took place in the 1930s and 1940s. ${ }^{1}$ The two museums focused on herethe Hiroshima Peace Memorial Museum and the Memorial Hall of the Victims in Nanjing Massacre by Japanese Invaders are arguably not only the most visited but also the most high-profile memory sites in their respective countries. They have both received UNESCO recognition and play key roles in highly publicized commemorative ceremonies.

Japanese peace museums tend to be explicitly described by those who operate them as vehicles for passing on the experiences of survivors to generations who have not themselves experienced war, in order for memory not to be forgotten through fading away. The Hiroshima Peace Memorial Museum is one of Japan's most visited museums with 1,680,923 visitors in 2017 (Hiroshima-shi 2018). As the Hiroshima survivors pass away, museum exhibits and lectures become ways 'to pass down the experience of the A-bomb survivors and to raise awareness about the importance of peace' (Hiroshima Peace Memorial Museum, n.d.). The museum's peace message is explicitly linked to calls for abolishing nuclear weapons and implies support for specific policies or goals, such as Japan's three non-nuclear principles of not manufacturing, not possessing and not harbouring nuclear weapons. In other words, the point is not just to remember for the sake of remembering but also to promote particular foreign policies.

It is not only the museum exhibition as such that is used to prevent forgetting. The museum hosts an annual high-profile ceremony on 6 August to commemorate the first ever use of an atomic bomb against human beings. Since 1951, the ceremony has included a speech, labelled a 'peace declaration', by the mayor of Hiroshima. The 2018 speech clearly stressed the dangers of forgetting: 'If the human family forgets history or stops confronting it, we could again commit a terrible error. That is precisely why we must continue talking about Hiroshima. Efforts to eliminate nuclear weapons must continue based on intelligent actions by leaders around the world' (Matsui 2018). In other words, protecting collective memory from forgetting as fading away is understood as necessary for securing peace.

In China, a key function of patriotic education, which focuses to a large extent on modern Chinese history, and especially the War of Resistance against Japan, is arguably to protect collective memory. Patriotic education, according to a key policy document, is meant to make Chinese understand how their forefathers remained indomitable in the face of foreign aggression and fought bloody wars for national independence under the pivotal leadership of the Chinese Communist Party, which is still in power. Education, then, seeks to make sure that certain episodes, interpreted in a particular way, are not forgotten. Such patriotic education is conducted not only at schools, but also through school visits to sites such as war museums, officially labelled 'patriotic education bases' (aiguozhuyi jiaoyu jidi) (Central Committee of the CPC 1994).

\footnotetext{
1 The museum exhibitions discussed in this article have been visited several times by the author. During these visits, the author has photographed exhibits, taken notes and purchased printed material covering the content of the exhibitions. Quotes from exhibitions are based on such material.
} 
One of the most prominent patriotic education bases is the Memorial Hall of the Victims in Nanjing Massacre by Japanese Invaders, which is one of the world's most visited museums with reportedly 8,000,000 visitors in 2014 (China Daily 2015). Former Chinese president $\mathrm{Hu}$ Jintao has pointed out that the museum is a good place to conduct patriotic education', and that: 'we can never forget this painful history' (quoted in Zhu and Zhang 2008: 292). The main exhibition's conclusion goes even further in stressing the importance of remembering as it states: 'To forget history is an act of betrayal'. The need for remembering is linked to future action in phrases such as: 'past experience, if not forgotten, serves as a guide for the future' (Zhu and Zhang 2008), and to the importance of supporting the Chinese Communist Party's policies and goals. As the exhibition's conclusion states: 'The Chinese people will unswervingly stick to the path of peaceful development and strive for the great rejuvenation of the Chinese people'. In other words, attempts are clearly made not only to make sure that particular episodes are not forgotten, but also to define the lessons the collective should learn from those memories.

Documents issued by the Chinese government have also stressed the educational importance of commemorating days of 'national shame' related to the War of Resistance against Japan (Central Committee of the CPC and the State Council 2004: 75-91). For example, in February 2014, it was reported that China had passed a law establishing the Memorial Day for the Nanjing Massacre victims (13 December) as a national commemoration day. The title of a newspaper article hinted at the reasons for adopting the legislation: 'Keeping the memory alive'. Similarly, the director of the Nanjing museum commented: 'Holding memorials through legislation safeguards the truth of the history of the Nanjing Massacre' (Global Times 2014). The Nanjing Memorial Day is a high-profile event where top leaders such as Xi Jinping deliver speeches.

It is clear that in both Japan and China these memorial sites, which are used for commemoration ceremonies on key anniversaries, offer opportunities for countering what is understood as the threat of forgetting as fading away. Importantly, the memory that is to be protected includes clearly stated lessons and goals that it is believed should be learned. Such lessons, moreover, function as justifications for specific foreign policies.

\section{Forgetting as denial}

The Nanjing museum exhibition's conclusion explicitly references the threat of forgetting as denial as it states that 'facts do not vanish simply because some people glibly insist on trying to deny them' and 'to deny a crime will only allow the crime to be repeated'. The museum also contains a section labelled 'Safeguarding Historical Truth', which includes a photograph of Chinese people protesting against the activities of Japanese right-wingers who deny the veracity of the Nanjing massacre.

The threat of forgetting as denial was a key motivation for the 2014 nomination for inscription of archival documents related to the Nanjing massacre in the UNESCO Memory of the World (MoW) Register. Even though it is better known for its museum exhibition, the Nanjing memorial hall also has an archival function. It 
houses documents and artefacts along with objects that have been created for the sole purpose of being exhibited, such as statues and paintings.

In 2015, UNESCO approved the application for inscription. During the application screening process, the Japanese government protested several times (Nakano 2018). For example, it commented that it was 'extremely regrettable' that China was 'using UNESCO for a political purpose' while explicating the Japanese government's official position that during the Nanjing massacre 'the killing of a large number of noncombatants, looting and other acts occurred', but that 'there are numerous theories as to the actual number of victims, and the Government of Japan believes it is difficult to say with any certainty' (Suga 2014). The official Japanese position thus does not deny that atrocious acts were committed in Nanjing. According to the official Chinese perspective as articulated in the exhibition in Nanjing, however, a victim count of 300,000 people, a figure literally set in stone at the Nanjing memorial hall, cannot be questioned. This means that the Japanese position that 'it is difficult to say with any certainty' how many were killed is nonetheless seen as constituting denial.

Following the decision to include the documents in the register, it was reported in China that: 'Researchers and the public cheered ... saying the inscription marks an "international recognition and consensus" of records that have been distorted by the Japanese right wing'. Similarly, museum curator Zhu Chengshan described the inscription as 'global recognition' and said that henceforth 'any act of denial will be impotent' (Xinhua 2015b, emphasis added). Furthermore, the Chinese Ministry of Foreign Affairs spokesperson Hua Chunying called the Nanjing massacre 'a historical fact recognized by the international community', and remarked that: '[f]acts should not be denied and history not re-written' (Xinhua 2015a). Similarly, curator Zhu commented: 'Seven decades have passed since WWII, but the lessons of war have not been learned in some countries, and that is why we applied to list the documents' (Xinhua 2015b). The purpose of the inscription was clearly to protect national collective memory from forgetting as denial by elevating Chinese memory to global memory.

Not only China but also Japan has sought to protect collective memory through UNESCO inscription. In 1996, the Hiroshima Peace Memorial was made a UNESCO World Heritage site. At the time, the Chinese delegation to UNESCO criticized the inscription, arguing that it was not Japan, but other Asian countries and peoples that suffered the most and that those who still attempt to 'deny this fact of history' could use the inscription for 'harmful purposes'. This, the Chinese delegation argued, would 'not be conducive to the safeguarding of world peace and security' (UNESCO 1996: Annex V).

\section{Forgetting as inherent to memory}

The empirics discussed above seem to fit well with the understandings of forgetting as fading away and as denial. The actors involved certainly appear to act based on such understandings. However, adopting a notion of forgetting as inherent to 
memory makes possible other interpretations. For such an approach, forgetting is key to constructing a coherent sense of self.

The official Japanese position on the Nanjing massacre referred to above is a case in point. Even though it acknowledges that 'a large number' of Chinese were killed, nothing is said about what exactly this means except that 'it is difficult to say with any certainty'. Officially describing the number in terms of uncertainty could be seen as a way of seeking to avoid acknowledging that it was an exceptionally large massacre and thereby seek to maintain a coherent and positive sense of self. The inscription of the Nanjing massacre documents by UNESCO provides the Chinese version of events - a version where there is no uncertainty whatsoever about the number of victims - with international recognition and gives it more attention internationally. In addition, by increasingly framing its war against Japan as part of a worldwide Anti-Fascist War and inviting foreign leaders to its military parade that commemorates the end of the war, the Chinese side has sought to link its memory to that of other states and to thereby gain allies in the contest with Japan over memory. All this arguably makes it more difficult for the Japanese side to dismiss the Chinese version and maintain a coherent sense of self.

The Chinese criticism of UNESCO's inscription of the Hiroshima Peace Memorial can be understood in a similar way. Remembering Japanese victimhood was said to be a potential threat both to the collective memory of other Asian states and to peace because the inscription of the site could be used for harmful purposes by those involved in forgetting as denial. The Chinese criticism of the Japanese memory of the atomic bombing of Hiroshima is not only that it forgets about the Chinese victims of Japan's war of aggression. The problem is also that Japanese are remembered as victims. It almost appears as if it is demanded not just that Japan remembers Chinese victims but also that it forgets Japanese ones. In other words, it is not just that the Japanese site forgets what the Chinese delegation considers it crucial to remember, but also that the Japanese memory reminded the Chinese delegation that forgetting is inherent to their own remembering. Being reminded of its own forgetting arguably threatens China's coherent sense of self and leads it to criticize Japanese denial even more forcefully. It is perhaps the case that states criticize other states for failing to remember or for denying memories to avoid facing the fact that forgetting is inherent to their remembering as well.

\section{Conclusion}

This article has addressed why disputes over collective memory are so persistent. To do so, it has sought to move beyond the common focus on memory and instead argued for a greater engagement with recent work in memory studies on the concept of forgetting. Based on this approach, the analysis conducted above has highlighted the dominance of certain understandings of forgetting as one hitherto not acknowledged reason for why disputes over collective memory tend to be so persistent. The understanding of forgetting as fading away frames collective memory as always fundamentally threatened by forgetting and motivates actors to think of collective memory as always threatened. In other words, the article has demonstrated that collective 
memory tends to be understood in terms of security even in the absence of securitizing moves and even when collective memory is not threatened by an enemy.

The notion of forgetting as denial is also common among actors in Sino-Japanese memory politics. With this notion, forgetting comes to be ascribed to actors and memory politics becomes more confrontative. The case of the inscription of the Nanjing massacre archival documents clearly illustrates the centrality of this understanding of forgetting as a motivation for the inscription as well as how it involved a bilateral escalation of memory politics.

While those involved in international memory politics typically appear to think about forgetting as fading away and as denial, they do not seem to embrace the third understanding - forgetting as inherent to memory. This article has used this understanding of forgetting as an analytical concept. As such, it has suggested that when an actor depicts or criticizes others for engaging in forgetting as denial, they do so not just to criticize them for forgetting, but perhaps more importantly to hide that they themselves are engaged in forgetting. Ascribing forgetting to others is thus a way of denying that forgetting is inherent to remembering. The threat of the other's memory is twofold: it forgets what we think ought to be remembered, but it also reminds us of our own forgetting. When the other state's collective memory receives international recognition through prestigious programs run by organizations such as UNESCO these threats are intensified and maintaining a coherent sense of self becomes increasingly difficult.

This suggests that for de-securitization of collective memory to take place, an understanding of forgetting as inherent to remembering needs to not only be used as an analytical lens, but it also needs to inform international memory politics as such. Awareness that forgetting is integral to remembering in general is necessary in order to recognize that it is not only others who forget, but that we also do so as we remember. Acknowledging that our remembering also involves forgetting could perhaps facilitate dialogue.

Funding Funding was provided by Marianne and Marcus Wallenberg Foundation (Grant No. 2016.0036).

\section{Compliance with ethical standards}

Conflict of interest There is no conflict of interest.

Open Access This article is licensed under a Creative Commons Attribution 4.0 International License, which permits use, sharing, adaptation, distribution and reproduction in any medium or format, as long as you give appropriate credit to the original author(s) and the source, provide a link to the Creative Commons licence, and indicate if changes were made. The images or other third party material in this article are included in the article's Creative Commons licence, unless indicated otherwise in a credit line to the material. If material is not included in the article's Creative Commons licence and your intended use is not permitted by statutory regulation or exceeds the permitted use, you will need to obtain permission directly from the copyright holder. To view a copy of this licence, visit http://creativecommons.org/ licenses/by/4.0/. 


\section{References}

Anderson, P. 2004. Union Sucré. London Review of Books 26(18): 10-16.

Assmann, A. 2011. From 'canon and archive'. In The collective memory reader, ed. J.K. Olick, V. Vinitzky-Seroussi, and D. Levy, 334-337. Oxford: Oxford University Press.

Auerbach, Y. 2009. The reconciliation pyramid: A narrative-based framework for analysing identity conflicts. Political Psychology 30(2): 291-318.

Augé, M. 2004. Oblivion. Minneapolis: University of Minnesota Press.

Bell, D. (ed.). 2006. Memory, trauma and world politics: Reflections on the relationship between the past and present. Basingstoke: Palgrave.

Buzan, B., O. Waever, and J. de Wilde. 1998. Security: A new framework for analysis. Boulder: Lynne Rienner Publishers.

Central Committee of the CPC. 1994. Aiguo zhuyi jiaoyu shishi gangyao [Outline on the implementation of patriotic education]. Beijing: Central Committee of the CPC.

Central Committee of the CPC and the State Council. [2004] 2006. Some opinions on further strengthening and improving the development of ideology and morality among minors. Chinese Education and Society 39(2): 75-91.

China Daily. 2015. Nanjing Massacre memorial sees record visitors on Tomb-Sweeping Day. 7 April, http://www.chinadaily.com.cn/regional/2015-04/07/content_20016034.htm. Accessed 23 May 2019.

Connerton, P. 2008. Seven types of forgetting. Memory Studies 1(1): 59-71.

Dian, M. 2017. Contested memories in Chinese and Japanese foreign policy. Cambridge, MA: Chandos Publishing.

Edkins, J. 2003. Trauma and the memory of politics. Cambridge: Cambridge University Press.

Erdelyi, M.H. 2008. Forgetting and remembering in psychology: Commentary on Paul Connerton's 'Seven types of forgetting'. Memory Studies 1(3): 273-278.

Fukuoka, K. 2018. Japanese history textbook controversy at a crossroads? Joint history research, politicization of textbook adoption process, and apology fatigue in Japan. Global Change, Peace and Security 30(3): 313-334.

Global Times. 2014. Keeping the memory alive. 27 February, http://globaltimes.cn/content/845248.shtml . Accessed 23 May 2019.

Gustafsson, K. 2014. Memory politics and ontological security in Sino-Japanese relations. Asian Studies Review 38(1): 71-86.

Gustafsson, K. 2019a. Temporal othering, de-securitisation and apologies: Understanding Japanese security policy change. Journal of International Relations and Development. https://doi.org/10.1057/ s41268-018-00168-y.

Gustafsson, K. 2019b. International reconciliation on the Internet? Ontological security, attribution and the construction of war memory narratives in Wikipedia. International Relations. https://doi. org/10.1177/0047117819864410.

Halbwachs, M. 1992. On collective memory. Chicago: Chicago University Press.

He, Y. 2009. The search for reconciliation: Sino-Japanese and German-Polish relations since world war II. Cambridge: Cambridge University Press.

Hiroshima Peace Memorial Museum website. (n.d.) Testimonies and lectures. http://hpmmuseum.jp/ modules/info/index.php?action=PageView\&page_id=159\&lang=eng. Accessed 10 Dec 2019.

Hiroshima-shi. 2018. Hiroshima heiwa kinen shiryōkan no nyūkanshasū nado no jōkyō ni tsuite [Concerning the Hiroshima Peace Memorial Museum's number of visitors]. http://www.city.hiroshima. lg.jp/www/contents/1522829291624/files/01.pdf. Accessed 10 Dec 2019.

Huyssen, A. 2000. Present pasts: Media, politics, amnesia. Public Culture 12(1): 21-38.

Khoury, N. 2018. Plotting stories after war: Toward a methodology for negotiating identity. European Journal of International Relations 24(2): 367-390.

Klymenko, L. 2016. The Holodomor law and national trauma construction in Ukraine. Canadian Slavonic Papers 58(4): 341-361.

Klymenko, L. 2019. Understanding the Donbas war in terms of World War II: A metaphor analysis of the armed conflict in Eastern Ukraine. Ethnopolitics. https://doi.org/10.1080/17449057.2019.1608064.

Laffey, M., and J. Weldes. 2008. Decolonising the Cuban missile crisis. International Studies Quarterly 52(3): 555-577. 
Langenbacher, E. 2010. Collective memory as a factor in political culture and International Relations. In Power and the past: Collective memory and international relations, ed. E. Langenbacher and Y. Shain, 13-49. Washington, DC: Georgetown University Press.

Lawson, S., and S. Tannaka. 2010. War memories and Japan's 'normalization' as an international actor: A critical analysis. European Journal of International Relations 17(3): 405-428.

Lind, J. 2008. Sorry states: Apologies in international politics. Ithaca: Cornell University Press.

Mälksoo, M. 2014. Criminalizing communism: Transnational mnemopolitics in Europe. International Political Sociology 8(1): 82-99.

Mälksoo, M. 2015. Memory must be defended: Beyond the politics of mnemonical security. Security Dialogue 46(3): 221-237.

Mannergren Selimovic, J. 2017. Gender, narrative and affect: Top-down politics of commemoration in post-genocide Rwanda. Memory Studies. https://doi.org/10.1177/1750698017730869.

Matsui, K. 2018. The city of Hiroshima peace declaration. 6 August, http://www.city.hiroshima.lg.jp/ www/contents/1317948556078/simple/H30english.pdf. Accessed 21 May 2019.

Müller, J.-W. (ed.). 2002. Memory and power in post-war Europe: Studies in the presence of the past. Cambridge: Cambridge University Press.

Nakano, R. 2018. A failure of global documentary heritage? UNESCO's 'memory of the world' and heritage dissonance in East Asia. Contemporary Politics 24(4): 481-496.

Nora, P. 1996. Realms of memory. New York: Columbia University Press.

Olick, J.K., V. Vinitzky-Seroussi, and D. Levy. 2011. Introduction. In The collective memory reader, ed. J.K. Olick, V. Vinitzky-Seroussi, and D. Levy, 3-62. Oxford: Oxford University Press.

Plate, L. 2016. Amnesiology: Towards the study of cultural oblivion. Memory Studies 9(2): 143-155.

Pugliese, G., and A. Insisa. 2017. Sino-Japanese power politics: Might, money and minds. London: Palgrave Macmillan.

Pusca, A. 2014. Looking back: Communist melancholia and post-socialist pains. Journal of International Relations and Development 17(3): 425-437.

Resende, E., and D. Budryte (eds.). 2013. Memory and trauma in international relations: Theories, cases and debates. London: Routledge.

Rose, C. 2005. Sino-Japanese relations: Facing the past, looking to the future?. London: Routledge.

Rumelili, B. 2018. Breaking with Europe's pasts: Memory, reconciliation, and ontological (in)security. European Security 27(3): 280-295.

Saito, H. 2016. The history problem: The politics of war commemoration in East Asia. Honolulu: University of Hawai'i Press.

Shibata, R. 2016. Japan's identity crisis and Sino-Japanese relations. In Disasters and social crisis in contemporary Japan: Political, religious, and sociocultural responses, ed. M.R. Mullins and K. Nakano, 81-103. Basingstoke: Palgrave Macmillan.

Siddi, M. 2017. The Ukraine crisis and European memory politics after the Second World War. European Politics and Society 18(4): 465-479.

Singer, J.A., and M.A. Conway. 2008. Should we forget forgetting? Memory Studies 1(3): 279-285.

Steele, B.J. 2008. Ontological security in international relations: Self-identity and the IR State. New York: Routledge.

Stone, C.B., and W. Hirst. 2014. (Induced) forgetting to form a collective memory. Memory Studies 7(3): 314-327.

Strukov, V., and V. Apryshchenko (eds.). 2018. Memory and securitization in contemporary Europe. London: Palgrave Macmillan.

Subotić, J. 2019a. Political memory after state death: The abandoned Yugoslav national pavilion at Auschwitz. Cambridge Review of International Affairs 32(3): 245-262.

Subotić, J. 2019b. Foreign policy and physical sites of memory: Competing foreign policies at the Jasenovac memorial site. International Politics. https://doi.org/10.1057/s41311-019-00204-9.

Suga, Y. 2014. Press conference by the Chief Cabinet Secretary (Excerpt). 11 June, https://japan.kante i.go.jp/tyoukanpress/201406/11_a.html. Accessed 25 Jan 2019.

Suzuki, S. 2008. Can apology serve as a security policy? Responsible scholarship and breaking the chains of negative history in Sino-Japanese relations. Korean Journal of Defense Analysis 20(4): 319-333.

Tōdō, A., A. Matsumoto, A. Takeda, and Y. Kanō. 2018. Kanjigen, kaitei dairokuban (Origin of Chinese characters, 6th ed. Tōkyō: Gakken.

UNESCO. 1972. Convention concerning the protection of the world cultural and natural heritage. New York: UNESCO. 
UNESCO. 1996. Convention concerning the protection of the world cultural and natural heritage: World heritage committee twentieth session. New York: UNESCO.

Wang, Z. 2012. Never forget national humiliation: Historical memory in Chinese politics and foreign relations. New York, NY: Columbia University Press.

Wessel, I., and M.L. Moulds. 2008a. How many types of forgetting? Comments on Connerton (2008). Memory Studies 1(3): 287-294.

Wessel, I., and M.L. Moulds. 2008b. Collective memory: A perspective from (experimental) clinical psychology. Memory 16(3): 288-304.

Whitehead, A. 2009. Memory. London: Routledge.

Xinhua. 2015a. China hails UNESCO listing of Nanjing massacre files. 10 October, http://www.china .org.cn/world/2015-10/10/content_36785003.htm. Accessed 30 Jan 2019.

Xinhua. 2015b. UNESCO listing of Nanjing massacre shows global consensus. 10 October, http://www. china.org.cn/china/2015-10/10/content_36781283.htm. Accessed 29 Jan 2019.

Zarakol, A. 2010. Ontological (in)security and state denial of historical crimes: Turkey and Japan. International Relations 24(1): 3-23.

Zehfuss, M. 2007. Wounds of memory: The politics of war in Germany. Cambridge: Cambridge University Press.

Zhu, C., and Q. Zhang. 2008. Qinhua rijun Nanjing datusha yunan tongbao jinianguan chenzhan tuji [Collected images of the exhibition of the Memorial Hall of the victims in the Nanjing massacre by Japanese invaders]. Beijing: Changcheng chubanshe.

Zon, D.H. 1999. UNESCO memory of the world program: The Asia-Pacific strategy. Kuala Lumpur: National Archives of Malaysia. https://web.archive.org/web/20050228192535/http://www.geocities. com/seapavaa/whatsnew/memory.htm. Accessed 9 Dec 2019.

Publisher's Note Springer Nature remains neutral with regard to jurisdictional claims in published maps and institutional affiliations. 